\title{
STARTING MATERIAL FOR BREEDING SPRING EMMER (TRITICUM DICOCCUM SHRANK.) OF GROATS USE
}

\author{
L. A. Vecherska ${ }^{1 *}$, V. V. Liubych ${ }^{2}$, L. I. Relina ${ }^{1}$, \\ O. V. Golik ${ }^{1}$, V.M. Suchkova ${ }^{3}$, R. L. Bohuslavskyi ${ }^{1}$ \\ ${ }^{1}$ Plant Production Institute named after V. Ya. Yuriev NAAS, \\ 142, Moskovskyi prosp., Kharkiv, Ukraine, 61000 \\ ${ }^{2}$ Uman National University of Horticulture, \\ 1, Instytutska Str., Uman, Cherkasy region, Ukraine, 20305 \\ ${ }^{3}$ National Academy of Agrarian Sciences of Ukraine, \\ 9, Mykhayla Omelianovycha-Pavlenka str., Kyiv, Ukraine, 01010
}

E-mail: lyudmila_vecherska@ukr.net*,lyubichv@gmail.com,lianaisaakovna@gmail.com,golik.oleg.vi@gmail.com, vsuchkova@ukr.net,boguslavr@meta.ua

Received February 16, 2020 / Received June 10, 2021 / Accepted July 19, 2021

\begin{abstract}
Aim. To explore sources of high groats properties among the genetic diversity of emmer and related species. Methods. Biochemical: The protein content was determined by Kjeldahl digestion; the starch content - by infrared spectroscopy. Technological: the vitreousness was determined by cutting 100 caryopses and expressed as percentages. The hull content, expressed in percent, was estimated as the ratio of hulled caryopses to the total of fully threshed ones. The gluten content and quality were assessed by manual washing-out. The hardness was determined on a YPD-300 hardness tester (Ltpm China) as the force in newtons required for caryopsis destruction. Emmer groats were obtained on a laboratory peeler UShZ-1. The groats properties were evaluated according to the method described in a utility model patent No. 129205. Statistical: the significance of differences between accessions was assessed using the Mann-Whitney test for small samples with unknown distribution. Two-factor analysis of variance considered 2 factors - genotype and year conditions. Pearson's test was used in the correlation analysis. The variability of traits was assessed by the coefficient of variation (CV). Results. The yields of emmer and durum wheat accessions and varieties as well as lines derived from emmer-wheat hybrids were measured and analyzed in 2016-2019. The yields of most emmer accessions (except for T. timopheevii) were similar to that of the check emmer variety Holikovska $\left(286 \pm 15 \mathrm{~g} / \mathrm{m}^{2}\right)$. The highest contents of protein and gluten were found in T. timopheevii (18.1 $\pm 0.4 \%$ and $40.5 \pm 1.8 \%$, respectively), Triticum durum Desf. var. falcatomelanopus Jakubz. \& Filat. (17.5 \pm $\pm 1.0 \%$ and $40.4 \pm 1.4 \%$ ), autochthonous variety Polba $3(16.8 \pm 0.1 \%$ and $36.9 \pm 1.1 \%)$, and line 10-139 $(14.8 \pm 0.8 \%$ and $29.0 \pm 2.4 \%)$. The gluten quality of most lines, derived from crossing spring emmer with durum wheat, corresponds to quality group I (good), and the gluten deformation index (GDI) is 50-75 units. $T$. timopheevii and T. durum var. falcatomelanopus were noticeable for vitreousness $(99 \pm 1 \%$ and $75 \pm 5 \%$, respectively). The grain hardness of the accessions under investigation varied from $151 \pm 15 \mathrm{~N}$ in variety Romanivska to $286 \pm$ $\pm 3 \mathrm{~N}$ in T. timopheevii. Lines 10-79 $(255 \pm 6 \mathrm{~N}), 10-65(220 \pm 10 \mathrm{~N})$ and T. durum var. falcatomelanopus $(268 \pm 6 \mathrm{~N})$ were characterized by high hardness, which exceeded that of durum wheat variety Spadshchyna $(152 \pm$ $\pm 13 \mathrm{~N})$. High outputs of groats were intrinsic to line 10-139 (96.2 $\pm 0.8 \%)$, line 10-79 (90.6 $\pm 0.8 \%)$, T. timopheevii $(92.0 \pm 0.1 \%)$, and durum wheat Spadshchyna $(91.4 \pm 0.5 \%)$. All the studied accessions showed low variability $(<10 \%)$ of grain hardness. Conclusions. It was found that by the set of groats properties (groats output and cooking coefficient in combination with good palatability, aroma, consistency, and also easy threshing), breeding lines 10-79 and 10-139, which are recommended to submit to trials as sources of groats qualities, have been distinguished. T. timopheevii and T. durum var. falcatomelanopus can be used as stand-alone groats crops, but in this case, they need improvement via breeding in terms of agronomic characteristics.
\end{abstract}

Key words: Triticum dicoccum, T. timopheevii, T. durum, groats properties, hull content, protein, gluten, grain hardness.

DOI: https://doi.org/10.15407/agrisp8.02.062

(C) L. A. VECHERSKA, V. V. LIUBYCH, L. I. RELINA, O. V. GOLIK, V.M. SUCHKOVA, R. L. BOHUSLAVSKYI, 2021 


\section{INTRODUCTION}

As the evidential base for the role of diet in reducing the risk of chronic diseases expands, consumers prefer groats with higher content of dietary fibers, antioxidants, and low glycemic index (Gorelick J et al, 2017; Shewry PR, Hey SJ, 2015). Emmer grain is used to produce high quality groats (hulled kernels of various cereal grains, used as basis for soups and porridges, some of them including those of emmer and durum are grains without germ and bran, which are finely crushed and then polished) (Yilmaz VA, 2020; Vasyliev SV, 2017). Among different wheat varieties, emmer wheat (Triticum dicoccum or T. turgidum subsp. dicoccum) is considered to be healthy food, even superfood (Karagöz A, 2014; Righetti L et al, 2016; Zaharieva et al, 2010) because emmer is rich in bioactive compounds, dietary fibers, and emmer starch is digested more slowly than that of other wheat species (Thorup AC et al, 2014; Lachman J et al, 2012; Kulathunga et al, 2021). The assortment of dishes (including groats) that can be made from emmer is particularized in Zaharieva et. al (2010). Within the framework of cooperation with the EU, Ukraine has considerably increased its supplies of grain processing products (including groats) to the EU market within five last years. Ukrainian groats are among top five products, imported to the EU. According to the EU Export HelpDesk, in 2016 the total delivery volume of these products was 2.6 thousand tons, with the Ukrainian share of $47 \%$ therein. All the abovementioned facts demonstrate the promising future of selecting emmer wheat varieties suitable for groats use.

The main problems in using traditional cultivated emmer varieties are low yield, fragility of wheat ears, and hull content. To date, these problems are partially solved via hybridization of emmer with modern wheat varieties, especially with durum wheat (T. durum or $T$. turgidum subsp. durum) which is closely related to $T$. dicoccum, (Vecherska LA et al, 2019). This crossing approach was used at the Plant Production Institute named after V. Ya. Yuriev (PPI) to select the emmer varieties Holikovska, Romanivska, and Yunika, which were introduced to the State Register of Plant Varieties Suitable for Dissemination in Ukraine in 2014, 2016 and 2020, respectively.

Our study aimed at exploring gene pool accessions and identifying sources of good groats properties among the genetic diversity of emmer and related species.

\section{MATERIALS AND METHODS}

In our study, we used accessions from the National Bank for Plant Genetic Resources of Ukraine and from the working collection of the Laboratory of Wheat Physiology and Breeding of the PPI: 1) varieties (Holikovska [State Registration Certificate No 150209 dated 02.05.2015], Romanivska [State Registration Certificate No 160888 dated 03.30.2016], Yunika [State Registration Certificate No 200614 dated 05.19.2020]) and lines (10-56, 10-65, 10-79, 10-139) of emmer hybrids derived via hybridization of spring emmer with spring durum wheat (the varieties and lines have been bred by us and included in the working collection); 2) autochthonous accession of spring emmer (variety Polba 3) (T. dicoccum) (National Bank); 3) spring durum wheat ( $T$. durum) varieties (Spadshchyna, Ukraine) (working collection) and Triticum durum var. falcatomelanopus (IR 00137, Syria) (National Bank); 4) Timopheev Emmer (T. timopheevii) (National Gene Bank). The National Bank for Plant Genetic Resources of Ukraine acquired accessions for its collection from other banks on exchange basis in compliance with the standards for gene banks (Plant Production and Protection Division, 2013).

The field experiments were conducted in the fields of the scientifically-based crop rotation of PPI, NAAS located in the eastern forest-steppe of Ukraine, in 20162019 (Khark Oblast, Kharkiv District; N 4959'39", E $\left.36^{\circ} 27^{\prime} 09^{\prime \prime}\right)$. The climatic conditions of the zone are temperate-continental with moderately cold winters and long, sometimes dry, hot summers and unstable humidity. The average annual air temperature is $+6-$ $8{ }^{\circ} \mathrm{C}$. The hydrothermal coefficient is close to 1 . The highest temperature is recorded in July $\left(+21^{\circ} \mathrm{C}\right)$, and the lowest - in January $\left(-7^{\circ} \mathrm{C}\right)$. The average annual temperature is $8.1{ }^{\circ} \mathrm{C}$. The sum of average daily temperatures above $10 \mathrm{C}$ for the period from May to September is $2500-2750{ }^{\circ} \mathrm{C}$, and the duration of the period with temperatures above $15^{\circ} \mathrm{C}$ ranges 100 to 120 days. The summer months are characterized by a high average daily air temperature, which in June reaches $+20.2{ }^{\circ} \mathrm{C}$, in July to $+21.4{ }^{\circ} \mathrm{C}$, and in August slightly decreases to $+19.6{ }^{\circ} \mathrm{C}$. The maximum temperature reaches $+38+41{ }^{\circ} \mathrm{C}$ and it can rise up to $+50{ }^{\circ} \mathrm{C}$ and above on the soil surface (Lipinsky VM et al, 2003). The annual precipitation ranges 476 to $536 \mathrm{~mm}$; the ave-rage amount of precipitation during the growing period is about $290 \mathrm{~mm}$. The distribution of precipitation during the year is uneven by months. In some years there are significant deviations in precipita- 
tion from the average. Evaporation significantly exceeds precipitation, especially in summer. The average relative humidity is $63 \%$. The largest portion of precipitation (240-440 $\mathrm{mm}$ ) falls during the warm period (May - September). Atmospheric droughts are relatively common.

The soil of the area under investigation is chornozem chernic calcic luvic loamic aric pachic (FAO and IUSS, 2015).

The weather data are provided by the Department of Agro-Industrial Development of Kharkiv Regional State Administration. During the vegetation period of wheat in 2016, the amount of precipitations exceeded the climate normal by $25 \%$, whereas in 2017-2019 it was 36-43\% lower (Table 1). So, in the last three years, weather conditions were drought-afflicted. In 2018 and 2019, the air temperature exceeded the perennial temperature by $17-19 \%$, in 2016 and 2017 the excess amounted to $8-9 \%$.

In 2018 and 2019, high temperatures and insufficient precipitations during the vegetation period of grain crops hindered the manifestation of genetic potential of yield and quality of grain, but allowed evaluating and differentiating accessions by such characteristics as yield, resistance to lodging, size and fullness of caryopsis, stable manifestation of improved traits of grain, and isolating the best genotypes, suitable for conditions in the eastern forest-steppe of Ukraine.

The registration area of a plot was $10 \mathrm{~m}^{2}$. The experiment plots were randomly located in blocks in four replications. Three samples were taken from each experimental plot. The sowing was done in optimal terms in rows with the inter-row spacing of $15 \mathrm{~cm}, 40$ seeds per 1 row. When harvesting, the threshing was done by the sheaf thresher MPSU-500 (Machine-Building

Table 1. Weather conditions during the vegetation period (April - August) 2016-2019

\begin{tabular}{c|c|c|c|c}
\hline \multirow{2}{*}{$\begin{array}{c}\text { Year } \\
\text { of study }\end{array}$} & \multicolumn{2}{|c|}{ Precipitation, $\mathrm{mm}$} & \multicolumn{2}{c}{ Air temperature, $\mathrm{t}^{\circ} \mathrm{C}$} \\
\cline { 2 - 5 } & sum & $\begin{array}{c}\text { \% of the } \\
\text { average } \\
\text { perennial } \\
\text { temperature }\end{array}$ & average & $\begin{array}{c}\% \text { of the } \\
\text { average } \\
\text { perennial } \\
\text { temperature }\end{array}$ \\
\hline 2019 & 187 & 64 & 64 & 119 \\
2018 & 182 & 62 & 62 & 117 \\
2017 & 167 & 57 & 57 & 108 \\
2016 & 367 & 125 & 125 & 109 \\
\hline
\end{tabular}

Plant of Experimental Constructions of the All-Russian Institute of Mechanization, Russian Federation). The performance data are presented at standard humidity (14\%) and $100 \%$ purity.

Biochemical methods. The protein content was determined by Kjeldahl digestion (S'aez-Plaza $\mathrm{P}$ et al, 2013a; S'aez-Plaza P et al, 2013b); the starch content by infrared spectroscopy (Chen Ye et al, 2017); the wet gluten content - by manual washing out until complete removal of starch. (Zhygunov D et al, 2017).

Technological methods. The vitreousness was determined by cutting 100 peeled caryopses which, depending on the cut consistency, were referred to one of three groups: vitreous, partially vitreous, and farinaceous (Tkachyk SO et al, 2016). The total vitreousness was expressed as a percentage in the ratio with 100 caryopses. While calculating the percentage of the total vitreousness, the number of partially vitreous caryopses was added to the number of completely vitreous caryopses. The hull content was estimated as the ratio between hulled caryopses and the total number of caryopses after threshing with sheaf thresher MPSU-500 and expressed in percent (\%). Emmer groats were obtained using a laboratory peeler UShZ-1 (LLC “OLIS”, Ukraine) designed to process the grain surface by the method of intense peeling of hulls. The weight of the investigated sample was $100 \mathrm{~g}$. In total, 4 samples of each accession were analyzed for each year. The grain was peeled for 120 $\mathrm{s}$. The groats properties were evaluated according to the method described in a utility model patent No. 129205 (Liubych VV et al, 2018) The groats properties were evaluated by boiling $50 \mathrm{~g}$ of groats in $200 \mathrm{~mL}$ of water with $1 \mathrm{~g}$ of sodium chloride on a water bath. The cooking time was defined, depending on the type of grain and groats. After cooling to $20{ }^{\circ} \mathrm{C}$, the color, odor, consistency, chewability, and palatability of cooked cereal were assessed using a 9-point scale. The cooking coefficient of the groats was determined by the formula:

$$
K=\frac{V k}{V k p},(\text { Tkachyk SO et al, 2016) }
$$

where $V k$ - porridge volume, cc; $V k p$ - groats volume, cc.

The hardness was determined on a YPD-300 hardness tester (Ltpm China) according to the method, developed by (Yarosh AV et al, 2014). The principle of the method is to measure the force (in newtons), required for caryopsis destruction. The caryopsis was 
placed horizontally, with its sulculus down, and crused on sides.

Statistical methods. The data are presented as the mean values of replicative measurements $(n=4)$. The statistical analysis of the data obtained was conducted in Microsoft Excel and StatgraphWin. The significance of differences between accessions was assessed using the Mann-Whitney test for small samples with unknown distribution (Lakin GF, 1990). Two-factor analysis of variance considered 2 factors - genotype and year conditions. The difference was deemed statistically significant at $\mathrm{p}<0.05$. Pearson's test was used in the correlation analysis (Lakin GF, 1990). The correlation was evaluated by Chaddock's scale: $0.1-0.3-$ insignificant correlation; $0.3-0.5$ - moderate; $0.5-0.7-$ significant; 0.7-0.9 - high; 0.9-0.99 - very high; 1functional (Chaddock RE, 1925). The analysis of variance and the variability of traits $(\mathrm{CV})$ were conducted as described in (Lakin GF, 1990).

\section{RESULTS}

In terms of yields, no accession under investigation exceeded significantly the controls (emmer variety Holikovska and durum wheat variety Spadshchyna). However, there was an evident tendency towards yield increase in Yunika variety $\left(338 \pm 35 \mathrm{~g} / \mathrm{m}^{2}\right)$ as compared with emmer variety Holikovska $(286 \pm 15 \mathrm{~g} /$ $\mathrm{m}^{2}$ ). The lowest yield was registered for T. timopheevii $\left(170 \pm 3 \mathrm{~g} / \mathrm{m}^{2}\right)$. The yield of most emmer accessions was at the level of the check variety Holikovska. T. $d u$ rum var. falcatomelanopus had lower yield than durum wheat variety Spadshchyna, although this difference is not statistically significant $\left(278 \pm 12 \mathrm{~g} / \mathrm{m}^{2}\right.$. and $317 \pm 15 \mathrm{~g} / \mathrm{m}^{2}$, respectively; $\mathrm{p}>0.05$ ) (Fig. 1).

The highest indices of protein content in caryopsis were noted for $T$. timopheevii $(18.1 \pm 0.4 \%), T$. $d u$ rum var. falcatomelanopus $(17.5 \pm 1.0 \%)$ T. dicoccum Polba $3(16.8 \pm 0.1 \%)$, line $10-139(14.8 \pm 0.8 \%)$ and emmer variety Holikovska (14.1 $\pm 1.0 \%$ ) (Table 2). The protein content in caryopsis of T. timopheevii, T. dicoccum Polba 3 and T. durum var. falcatomelanopus exceeded $(\mathrm{p}<0.01)$ this index for durum wheat variety Spadshchyna $(12.7 \pm 0.4 \%)$ and $(p<0.05)$ emmer variety Holikovska $(14.1 \pm 1.0 \%)$ (Table 2$)$.

Another component, characterizing the nutritional value of the groats is starch. The starch content in caryopses of accessions under investigation varied from $53.0 \pm 0.4 \%$ to $61.4 \pm 0.1 \%$. The highest starch content was noted for lines 10-56 (59.3 $\pm 0.4 \%)$ and Spadshchyna variety $(61.4 \pm 0.1 \%)$, which was significantly higher $(\mathrm{p}<0.05)$ as compared with Holikovska variety $(56.8 \pm 0.1 \%)$.

According to the results of evaluating the wet gluten content in caryopsis, the highest value was registered for the accessions of $T$. timopheevii $(40.5 \pm 1.8 \%)$, T. durum var. falcatomelanopus $(40.4 \pm 1.4 \%)$ and Polba 3 variety $(36.9 \pm 1.1 \%)$ (Table 2$)$. The gluten content in the indicated accessions was significantly $(\mathrm{p}<0.05)$ higher than in Holikovska variety (by 8.8 $12.4 \%)$ and $(p<0.01)$ durum wheat variety Spadshchyna (by $12.0-15.6 \%$ ).

In terms of GDI index, the gluten quality of most lines was 50-75 units. (Table 2), which corresponds to quality group I - good. The exceptions were found in lines 10-65, Unica variety, T. durum var. falcatomelanopus and $T$. timopheevii with gluten quality at the level of $80 \pm 2,95 \pm 4,100 \pm 3$ and $95 \pm 2$ un. Thus, GDI, corresponding to quality group II, is satisfactory, but poor. The gluten of Polba 3 variety with GDI $105 \pm 2$ was referred to quality group III - unsatisfactory and poor.

The highest level of vitreousness was noted for accessions: T. timopheevii $(99 \pm 1 \%)$ and $T$. durum var. falcatomelanopus $(75 \pm 5 \%)$, which was significantly higher than that for emmer variety Holikovska (by 19$43 \% ; \mathrm{p}<0.05)$ and durum wheat Spadshchyna (27$51 \% ; \mathrm{p}<0.01)$ (Table 2). In addition, the vitreousness of lines 10-79 (56 $\pm 14 \%), 10-65(59 \pm 16 \%), 10-56$ $(56 \pm 11 \%)$ and Yunika variety $(59 \pm 8 \%)$ was at the level of Holikovska variety $(56 \pm 12 \%)$.

The indices of hardness were the highest for T. timopheevii, T. durum var. falcatomelanopus, Holikovska, Yunika, 10-56, 10-65, and 10-79 with the range from $198 \pm 7 \mathrm{~N}$ to $286 \pm 3 \mathrm{~N}$. These accessions significantly $(\mathrm{p}<0.01)$ exceeded durum wheat Spadshchyna $(152 \pm 13 \mathrm{~N})$.

The hull content of varieties and hybrid lines under investigation was inherited from emmer, but weakened considerably (Fig. 2). Rather high output of peeled grain was noted for lines 10-79 $(92.7 \pm 0.7 \%), 10-65$ $(91.4 \pm 0.3 \%)$ and $10-139(85.0 \pm 1.1 \%)$, which exceeded the check variety in terms of this index significantly $(p<0.05)$, and $100 \%$ threshing was achieved for Yunika variety. High grain yield was noted also for emmer variety Romanivska $(95.1 \pm 1.2 \%)$, and $T$. $d u$ rum var. falcatomelanopus $(99.3 \pm 0.3 \%)$.

High outputs of groats were intrinsic to line 10-139 $(96.2 \pm 0.8 \%)$, line 10-79 (90.6 $\pm 0.8 \%)$, T. timopheevii $(92.0 \pm 0.1 \%)$, and durum wheat Spadshchyna $(91.4 \pm 0.5 \%)$, which is significantly higher as com- 


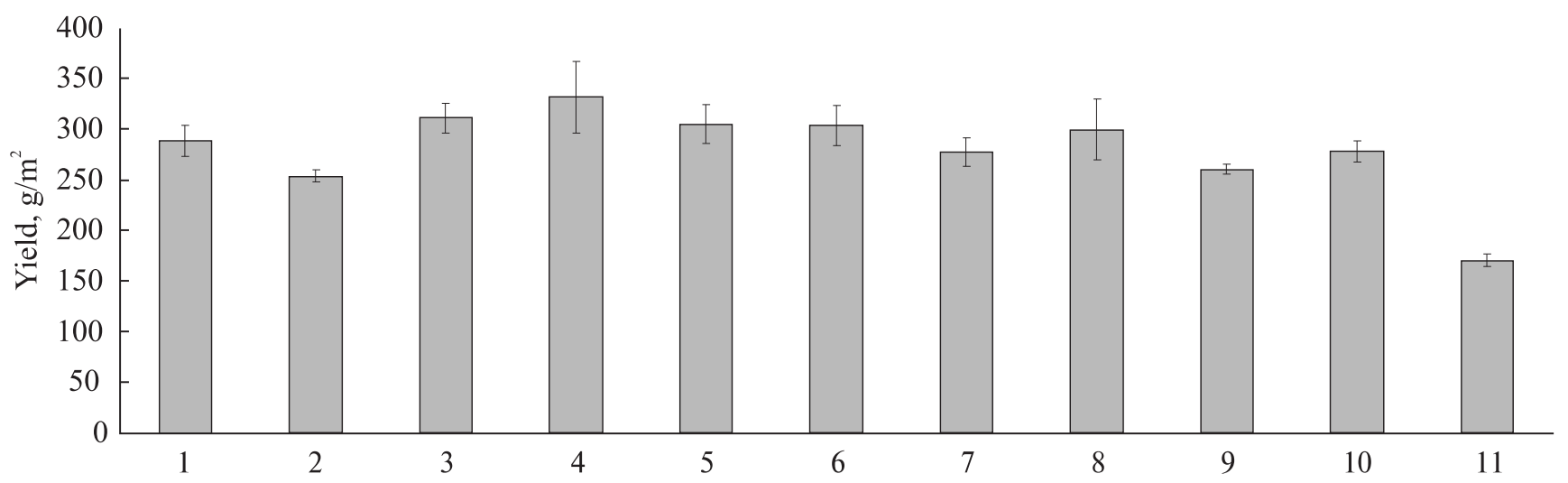

Fig. 1. The average yield of wheat accessions, 2016-2019, $\mathrm{M} \pm \mathrm{m} .1$ - Holikovska; 2 - Romanivska; 3 - Spadshchyna; 4 Yunika; 5-10-56; 6-10-65; 7 - 10-79; 8-1-139; 9 - Polba 3; $10-$ T. durum var. falcatomelanopus; $11-$ T. timopheevii

pared to Holikovska variety $(88.7 \pm 0.1 \%)$. Low output of groats was noted for line 10-56 (82.2 $\pm 0.3 \%)$ (Fig. 3).

The evaluation of groats quality indices demonstrated that the accessions did not differ in color (8 points), smell, palatability, and consistency, which were given the highest number of points for all the accessions 9 . The porridge color was yellow (durum wheat), light yellow (emmer-wheat hybrid line 10-56), or cream (Table 3). Other accessions had porridge of cream color. Hence, use of these accessions can satisfy different consumers' tastes and preferences.

The shortest cooking time was 25-30 min for Polba 3 variety, and the longest - 75 min for coarsegrained durum wheat $T$. durum var. falcatomelano- pus. The cooking of the remaining accessions took 40 min (Table 3). The cooking coefficient by volume was determined within the range of $2.7 \pm 0.1$ (T. durum var. falcatomelanopus) $-3.8 \pm 0.1$ (line 10-56). All varieties and lines of spring emmer, and Polba 3 variety exceeded spring durum wheat variety Spadshchyna in terms of the cooking coefficient by volume.

In general, the impact of the "genotype" factor on all the traits was higher as compared to the year factor (Table 4). This impact was manifested the most in terms of hardness and groats output - over $95 \%$.

A relevant characteristic of gene pool accessions as sources for groats quality for selection purposes is the stability of expression of the phenotypic traits such

Table 2. The biochemical and technological properties of wheat accessions, 2016-2019, $\mathrm{M} \pm \mathrm{m}$

\begin{tabular}{|c|c|c|c|c|c|c|c|}
\hline \multirow{2}{*}{ Genotype } & \multicolumn{3}{|c|}{ Content in caryopsis, $\%$} & \multicolumn{2}{|c|}{ Gluten quality } & \multirow{2}{*}{$\begin{array}{c}\text { Vitreousness, } \\
\%\end{array}$} & \multirow{2}{*}{$\begin{array}{l}\text { Hardness, } \\
\text { (N) }\end{array}$} \\
\hline & of protein & of starch & of gluten & GDI & GDI & & \\
\hline $\begin{array}{l}\text { Holikovska, emmer } \\
\text { control variety }\end{array}$ & $14.1 \pm 1.0$ & $56.8 \pm 0.1$ & $28.1 \pm 3.4$ & $70 \pm 4$ & 1 & $56 \pm 12$ & $198 \pm 7$ \\
\hline Romanivska & $13.7 \pm 1.1$ & $57.2 \pm 1.6$ & $26.9 \pm 3.6$ & $75 \pm 8$ & 1 & $44 \pm 10$ & $151 \pm 15$ \\
\hline $\begin{array}{l}\text { Spadshchyna durum } \\
\text { control variety }\end{array}$ & $12.7 \pm 0.4$ & $61.4 \pm 0.1^{*}$ & $24.9 \pm 3.1$ & $70 \pm 1^{*}$ & 1 & $48 \pm 6$ & $152 \pm 13$ \\
\hline 12-126 Yunika & $13.0 \pm 0.1$ & $57.2 \pm 1.2$ & $27.0 \pm 3.4$ & $95 \pm 4^{*}$ & 2 & $59 \pm 8$ & $214 \pm 11$ \\
\hline $10-56$ & $12.1 \pm 1.0$ & $59.3 \pm 0.4^{*}$ & $25.0 \pm 4.4$ & $60 \pm 2$ & 1 & $56 \pm 11$ & $215 \pm 8^{*}$ \\
\hline $10-65$ & $13.5 \pm 0.8$ & $58.5 \pm 0.9$ & $26.2 \pm 3.4$ & $80 \pm 2^{*}$ & 2 & $59 \pm 16$ & $220 \pm 10^{*}$ \\
\hline 10-79 & $13.4 \pm 0.9$ & $59.5 \pm 1.6$ & $25.1 \pm 3.5$ & $70 \pm 4$ & 1 & $56 \pm 14$ & $250 \pm 6^{* *}$ \\
\hline $10-139$ & $14.8 \pm 0.8$ & $58.1 \pm 1.3$ & $29.0 \pm 2.4$ & $50 \pm 1^{*}$ & 1 & $51 \pm 15$ & $159 \pm 9$ \\
\hline Polba 3 & $16.8 \pm 0.1^{*}$ & $55.9 \pm 0.2$ & $36.9 \pm 1.1^{*}$ & $105 \pm 2 *$ & 3 & $53 \pm 12$ & $204 \pm 15$ \\
\hline $\begin{array}{l}\text { T. durum var. falcato- } \\
\text { melanopus }\end{array}$ & $17.5 \pm 1.0^{*}$ & $53.7 \pm 0.2$ & $40.4 \pm 1.4^{*}$ & $100 \pm 3 *$ & 2 & $75 \pm 5^{*}$ & $268 \pm 6^{* *}$ \\
\hline T. timopheevii & $18.1 \pm 0.4 * *$ & $53.0 \pm 0.4$ & $40.5 \pm 1.8^{*}$ & $95 \pm 2 *$ & 2 & $99 \pm 1 * *$ & $286 \pm 3 * *$ \\
\hline
\end{tabular}

Note: *,* - differences from the check variety are significant at $\mathrm{p}<0.05$ and $\mathrm{p}<0.01$, respectively. 
STARTING MATERIAL FOR BREEDING SPRING EMMER (TRITICUM DICOCCUM SHRANK.)

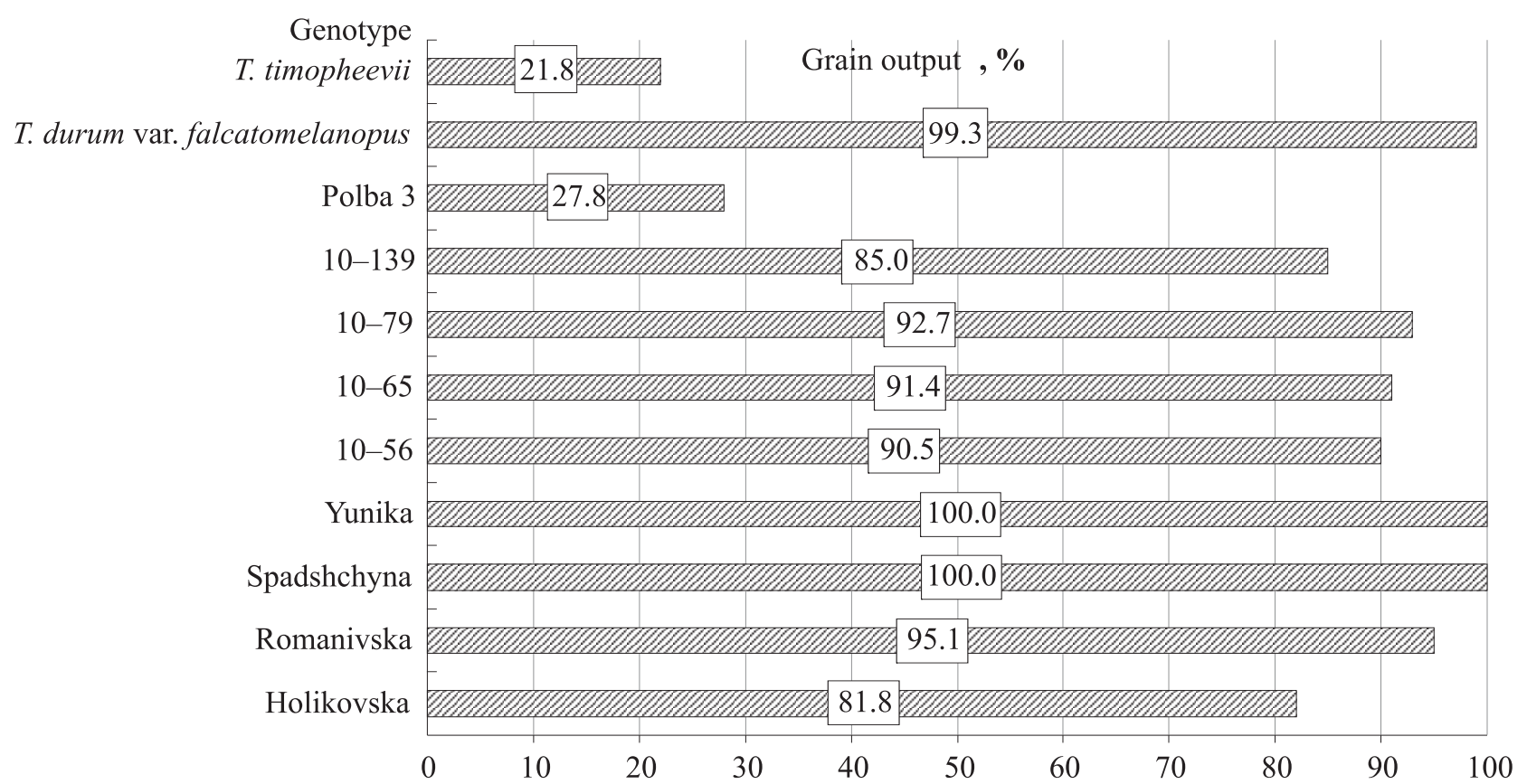

Fig. 2. The output of peeled grain in wheat accessions, 2016-2019, $\mathrm{M} \pm \mathrm{m}$

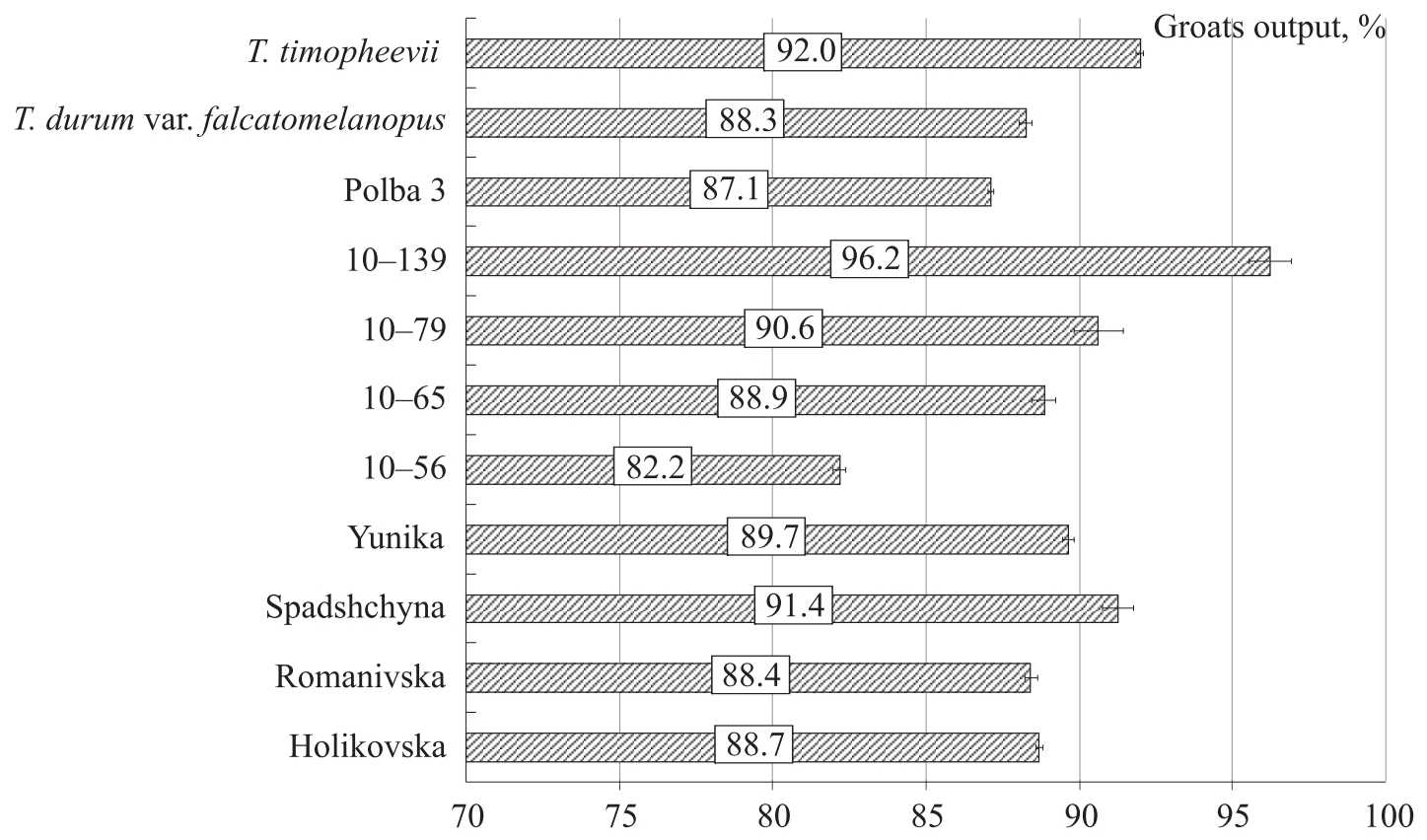

Fig. 3. The output of groats from wheat accessions, 2016-2019, $\mathrm{M} \pm \mathrm{m}$

as groats output, vitreousness, grain hardness starch content etc. In general, rather stable are the indices of groats output (CV from 0.1 to $1.7 \%$ ), starch content (0.2-4.2\%) and hardness (2.4-8.9\%) (Table 5).

Greater variability of accessions was noted for vitreousness $(0.8-32.0 \%)$, gluten $(6.0-28.2 \%)$ and protein $(1.2-15.9 \%)$ contents, yield (3.6-21.4\%).

Among the accessions under investigation, the least variable varieties in terms of yield were Roma- nivska (CV $4.8 \%)$, Polba 3 (3.6 \%) and T. ti-mopheevii (4.8\%). Line 10-139 and Yunika variety were characterized by rather high variability in terms of this trait (CV 19.9 and $21.4 \%$, respectively). Polba 3 was comparatively stable in protein and gluten content (CV 1.2 and $9.4 \%$ respectively), and Yuni$\mathrm{ka}$ - in the former of these traits $(2.2 \%)$. Stable vitreousness of caryopsis was also noted for $T$. durum var. falcatomelanopus (4.5\%) and T. timopheevii (0.8\%). 


\section{DISCUSSION}

Emmer is known to be inferior to durum wheat in yield indices, yet emmer wheat is more resistant to the abiotic stressors (higher temperature, insufficient moisture, high osmotic pressure) (Musienko MM et al, 2019; Smirnov O et al, 2020) and its yield indices are not lower than those for common wheat (Hütsch BW et al, 2018). Polba 3, the autochthonous emmer variety, demonstrated low yield (Fig. 1), but it had reliably higher indices of protein and gluten content in caryopsis than most other accessions (Table 2).

According to different data, protein content in emmer caryopsis may vary in a very wide range: from $3 \%$ to $37 \%$ (Shewry PR, Hey SJ, 2015; Čurná V, LackoBartošová M, 2017; Geisslitz S et al, 2019; Kulathunga et al, 2021; Bobryk-Mamczarz et al, 2021) depending on the genotype, region of cultivation, agrotechnology, and climate conditions. Protein content in the caryopses of accessions under our investigation was from $12.1 \%$ for line $10-56$ to $18.1 \%$ for $T$. timopheevii. These values are rather high, as, pursuant to the requirement of the State standard, grain of class I should contain $\geq 14.0 \%$ protein.

The wet gluten content in the accessions under investigation is generally in agreement with other researchers' data (Bobryk-Mamczarz et al, 2021), who reported that the wet gluten content in emmer was $38 \%$ and in durum wheat - 28.7-28.8\%. Emmer gluten is known for its weakness due to a higher content of gliadins and lower content of glutenins as compared with common wheat (Longin et al, 2015), so it is better digested by the human organism (Geisslitz S et al, 2019), which, in com- bination with slowly digested starch, gives grounds to recommend products, made of emmer, for a healthy diet.

The gluten quality of most lines, derived from crossing spring emmer wheat with spring durum wheat, amounted to 50-75 un. GDI (2), which corresponds to quality group I - good. The exceptions were found in lines 10-65, Yunica variety, T. durum var. falcatomelanopus and T. timopheevii with gluten quality, which corresponded to quality group II - satisfactory but poor (Table 2). It is noteworthy that according to DSTU 3768:2019 this index for durum wheat (close to emmer both genetically and in its use) is not limited.

Hardness, protein content, color, content and quality of gluten are the main parameters to evaluate the suitability of durum wheat for the production of bulgur and couscous grouts in countries of the Middle East, North Africa, and Turkey. The first three parameters should be maximally expressed, while gluten may have medium indices (Hammami R, Sissons M, 2020; Ozboy O, Koksel H, 2002). In addition, hard vitreous caryopses have better technological traits during threshing, peeling, and refinement. The value of the hardness index lies in the fact that it is a genetically conditioned, hereditary, varietal trait, manifested regardless of the vitreousness level of the caryopsis (Ma X et al, 2017; Nirmal RC et al, 2016). It is difficult to compare the data of different researchers since they use different methods and devices to measure the hardness. Based on the data, obtained by Veha A et al. (Veha A et al, 2011), we determined that $286 \mathrm{~N}$ approximately corresponds to HI 68. Comparing with the data of (Haraszi R et al, 2016; Haraszi R et al, 2013), we received similar result,

Table 3. The indices of groats quality for caryopses of wheat accessions, 2016-2019, $\mathrm{M} \pm \mathrm{m}$

\begin{tabular}{|c|c|c|c|}
\hline Genotype & $\begin{array}{l}\text { Cooking time, } \\
\min \end{array}$ & $\begin{array}{l}\text { Cooking coefficient } \\
\text { by volume }\end{array}$ & $\begin{array}{l}\text { Porridge } \\
\text { color }\end{array}$ \\
\hline $\begin{array}{l}\text { Holikovska, emmer control variety } \\
\text { Romanivska } \\
\text { Spadshchyna durum control variety } \\
12-126 \text { Yunika } \\
10-56 \\
10-65 \\
10-79 \\
10-139 \\
\text { Polba } 3 \\
\text { T. durum var. falcatomelanopus } \\
\text { T. timopheevii }\end{array}$ & $\begin{array}{l}40 \pm 1 \\
40 \pm 2 \\
40 \pm 1 \\
40 \pm 2 \\
40 \pm 1 \\
40 \pm 2 \\
40 \pm 2 \\
40 \pm 2 \\
25 \pm 2 * * \\
75 \pm 2 * * \\
40 \pm 3\end{array}$ & $\begin{array}{l}3.5 \pm 0.1 * \\
3.5 \pm 0.2^{*} \\
2.8 \pm 0.1 \\
3.1 \pm 0.1^{*} \\
3.8 \pm 0.1^{*} \\
3.5 \pm 0.2^{*} \\
3.7 \pm 0.2^{*} \\
3.2 \pm 0.1 * \\
3.7 \pm 0.2^{*} \\
2.7 \pm 0.1 \\
3.0 \pm 0.2\end{array}$ & $\begin{array}{l}\text { cream } \\
\text { cream } \\
\text { yellow } \\
\text { cream } \\
\text { light yellow } \\
\text { cream } \\
\text { cream } \\
\text { cream } \\
\text { cream } \\
\text { yellow } \\
\text { cream }\end{array}$ \\
\hline
\end{tabular}

Note. $* * *$ - differences from the check durum wheat variety Spadshchyna are significant at $\mathrm{p}<0.05$ and $\mathrm{p}<0.01$ respectively. 
meaning that T. timopheevii, T. durum var. falcatomelanopus and lines 10-79, 10-65 belong to durum wheat or durum/medium-hard durum wheat according to the classification of Haraszi et al. (Haraszi R et al, 2016; Haraszi R et al, 2013), though some researchers (Kulathunga et al., 2021) reported even higher HI values for their emmer accessions (around 74).
The highest indices of protein and gluten content, vitreousness and hardness were noted for T. durum var. falcatomelanopus and T. timopheevii (Table 2). It is important that the former accession has very large grain (according to our data, the weight of 1,000 grains over $55 \mathrm{~g}$ ), which is easily threshed and highly regarded at the international market due to

Table 4. The results of the analysis of variance, biochemical and technological indices of tetraploid spring wheat varieties, 2016-2019

\begin{tabular}{|c|c|c|c|c|c|c|}
\hline Variation factor & $\begin{array}{l}\text { Degrees of } \\
\text { freedom, df }\end{array}$ & $\begin{array}{c}\text { Sum of squared } \\
\text { deviations, } \\
\text { SSD }\end{array}$ & $\begin{array}{c}\text { Mean square, } \\
\text { MS }\end{array}$ & Actual F-test, F & $\begin{array}{c}\text { Level of } \\
\text { significance, } \mathrm{S}\end{array}$ & Factor effect \\
\hline \multicolumn{7}{|c|}{ Yield } \\
\hline $\begin{array}{l}\text { Total } \\
\text { Genotypes } \\
\text { Years } \\
\text { Errors }\end{array}$ & $\begin{array}{c}10 \\
3 \\
30\end{array}$ & $\begin{array}{c}116,347.0 \\
73,697.7 \\
9,997.0 \\
32,652.3\end{array}$ & $\begin{array}{l}7,369.8 \\
3,332.4 \\
1,088.4\end{array}$ & $\begin{array}{l}6.8 \\
3.1\end{array}$ & $\begin{array}{c}0.000 \\
0.04\end{array}$ & $\begin{array}{c}63.3 \\
8.6 \\
28.1 \\
\end{array}$ \\
\hline \multicolumn{7}{|c|}{ Protein content } \\
\hline $\begin{array}{l}\text { Total } \\
\text { Genotypes } \\
\text { Years } \\
\text { Errors }\end{array}$ & $\begin{array}{c}10 \\
3 \\
30\end{array}$ & $\begin{array}{c}231.1 \\
166.6 \\
15.7 \\
48.8 \\
\end{array}$ & $\begin{array}{c}16.7 \\
5.2 \\
1.6 \\
\end{array}$ & $\begin{array}{c}10.2 \\
3.2\end{array}$ & $\begin{array}{c}0 \\
0.099\end{array}$ & $\begin{array}{l}72.1 \\
6.8\end{array}$ \\
\hline \multicolumn{7}{|c|}{ Starch content } \\
\hline $\begin{array}{l}\text { Total } \\
\text { Genotypes } \\
\text { Years } \\
\text { Errors }\end{array}$ & $\begin{array}{c}10 \\
3 \\
30 \\
\end{array}$ & $\begin{array}{c}305.4 \\
246.1 \\
14.3 \\
45.0 \\
\end{array}$ & $\begin{array}{c}24.6 \\
4.8 \\
1.5 \\
\end{array}$ & $\begin{array}{c}16.4 \\
3.2\end{array}$ & $\begin{array}{c}0 \\
0.037\end{array}$ & $\begin{array}{c}80.6 \\
4.7\end{array}$ \\
\hline \multicolumn{7}{|c|}{ Wet gluten content } \\
\hline $\begin{array}{l}\text { Total } \\
\text { Genotypes } \\
\text { Years } \\
\text { Errors }\end{array}$ & $\begin{array}{c}10 \\
3 \\
30 \\
\end{array}$ & $\begin{array}{c}2621.9 \\
1,518.6 \\
438.3 \\
665.0 \\
\end{array}$ & $\begin{array}{c}151.9 \\
146.1 \\
22.2 \\
\end{array}$ & $\begin{array}{l}6.9 \\
6.6\end{array}$ & $\begin{array}{c}0 \\
0.001\end{array}$ & $\begin{array}{l}57.9 \\
16.7\end{array}$ \\
\hline \multicolumn{7}{|c|}{ Vitreousness } \\
\hline $\begin{array}{l}\text { Total } \\
\text { Genotypes } \\
\text { Years } \\
\text { Errors } \\
\end{array}$ & $\begin{array}{c}10 \\
3 \\
30 \\
\end{array}$ & $\begin{array}{c}15,756.5 \\
9,298.5 \\
4,129.3 \\
2,328.7 \\
\end{array}$ & $\begin{array}{c}929.9 \\
1,376.4 \\
77.6\end{array}$ & $\begin{array}{l}12.0 \\
17.7\end{array}$ & $\begin{array}{l}0 \\
0\end{array}$ & $\begin{array}{l}59.0 \\
26.2\end{array}$ \\
\hline \multicolumn{7}{|c|}{ Hardness } \\
\hline $\begin{array}{l}\text { Total } \\
\text { Genotypes } \\
\text { Years } \\
\text { Errors }\end{array}$ & $\begin{array}{c}10 \\
3 \\
30 \\
\end{array}$ & $\begin{array}{c}85,998.4 \\
82,434.7 \\
716.3 \\
2,847.5 \\
\end{array}$ & $\begin{array}{c}8,243.5 \\
238.8 \\
94.9\end{array}$ & $\begin{array}{l}86.8 \\
2.5\end{array}$ & $\begin{array}{c}0 \\
0.077\end{array}$ & $\begin{array}{c}95.9 \\
0.8\end{array}$ \\
\hline \multicolumn{7}{|c|}{ Groats output } \\
\hline $\begin{array}{l}\text { Total } \\
\text { Genotypes } \\
\text { Years } \\
\text { Errors }\end{array}$ & $\begin{array}{c}10 \\
3 \\
30\end{array}$ & $\begin{array}{c}496.4 \\
474.5 \\
4.0 \\
17.8\end{array}$ & $\begin{array}{l}47.5 \\
1.3 \\
0.6\end{array}$ & $\begin{array}{c}80.1 \\
2.3\end{array}$ & $\begin{array}{c}0 \\
0.998\end{array}$ & $\begin{array}{c}95.6 \\
0.8\end{array}$ \\
\hline
\end{tabular}


this characteristic. T. durum var. falcatomelanopus (falcate durum wheat) is often supplied to the global market under the name of kamut. This is not accurate, since classic kamut is another variety of wheat: khorasan wheat or T. turanicum Jakubz. Still, a particular reason for this substitution is found in similar characteristics of grain of both forms (Dorofeev VF et al, 1987). T. turanicum is adjusted to the conditions of warm climate and irrigation, so it is poorly suitable for cultivation in the eastern Forest-Steppe of Ukraine. Like most territory of Ukraine, in this region it is reasonable to obtain grain for the production of groats from $T$. durum var. falcatomelanopus with the yield index of $2.8 \mathrm{t} / \mathrm{ha}$ and more.

The starch content in the accessions under investigation ranged $53.0 \pm 0.4 \%$ to $61.4 \pm 0.1 \%$, which is somewhat lower than the values $(64.3-66.9 \%)$ reported by other researchers (Kulathunga et al., 2021). The contents of starch and protein are in a negative dependence. At the same time, starch in the caryopsis of kamut is largely "resistant" - it is slowly fermented into sugars in the human organism, so it is more suitable for people, who have type II diabetes and/or are inclined to corpulence (Sofi F et al, 2013).

One of the problems, faced by emmer processors, is its hull content. This trait of emmer is traditionally viewed negatively, since peeling grain from hulls requires special peeling equipment, more energy and time. However, at present, researchers consider hull content of emmer as an advantage as compared with wheat varieties with naked grain. Hulled accessions had higher performance, were more stable to biotic factors, and ripened earlier (Kohl S et al, 2015). Hulls preserve their metabolic activity longer than other vegetative organs, and impact protein accumulation in grain (Okamoto Y, Takumi S et al, 2013) in comparison with naked accessions.

The hybridization of emmer with durum wheat was successfully used for partial improvement of the threshing level. The hull content of hybrid lines under our investigation was inherited from emmer, but weakened considerably (Fig. 2). On the one hand, such hull content does not hinder mechanic threshing, but on the other hand - in case of rains it is better than in durum wheat, protecting caryopses from fast moisturization which causes starch hydrolysis and loss of saleable condition of grain and reduces storage duration.

Our results show that the emmer wheat accessions under investigation correspond to the main requirements, used to evaluate the suitability of durum wheat for groats production. Emmer wheat accessions in our hands were not inferior to or, by some indices (protein content, gluten content, vitreousness, and hardness) even superior to the control spring durum wheat variety Spadshchyna.

The cooking coefficients in terms of volume and duration of cooking are some of the most important groats traits. A rather high (3.7-3.8) cooking coefficient was noted for Polba 3, lines 10-56, 10-79; comparatively low coefficient - for durum wheat accessions Spadshchyna and T. durum var. falcatomelanopus (2.7-2.8) (Table 3). The cooking coefficient of the remaining accessions was 3.4-3.5. All varieties and lines of em-

Table 5. The variability of biochemical and technological traits of caryopsis quality of spring tetraploid wheat species, 2016-2019

\begin{tabular}{l|c|c|c|c|c|c|c}
\hline \multirow{2}{*}{\multicolumn{1}{c}{ Variety/line }} & \multicolumn{5}{c}{ Variation coefficient, \% } \\
\cline { 2 - 7 } & Yield & $\begin{array}{c}\text { protein } \\
\text { content }\end{array}$ & $\begin{array}{c}\text { gluten } \\
\text { content }\end{array}$ & $\begin{array}{c}\text { starch } \\
\text { content }\end{array}$ & vitreousness & hardness & $\begin{array}{c}\text { output } \\
\text { of groats }\end{array}$ \\
\hline Holikovska emmer control variety & 10.5 & 13.7 & 23.8 & 0.1 & 23.8 & 6.4 & 0.1 \\
Romanivska & 4.8 & 15.9 & 26.6 & 3.9 & 28.5 & 4.6 & 0.5 \\
Durum control variety Spadshchyna & 9.6 & 6.9 & 25.2 & 0.2 & 14.0 & 5.1 & 1.1 \\
12-126 Yunika & 21.4 & 2.2 & 25.1 & 2.9 & 17.1 & 3.3 & 0.4 \\
10-56 & 8.4 & 7.6 & 21.7 & 1.1 & 21.3 & 7.9 & 0.6 \\
10-65 & 13.0 & 11.2 & 26.3 & 2.2 & 32.0 & 3.3 & 1.0 \\
10-79 & 10.4 & 12.8 & 28.2 & 4.2 & 30.0 & 2.9 & 1.7 \\
10-139 & 19.9 & 11.0 & 16.6 & 3.3 & 30.5 & 4.0 & 1.5 \\
Polba 3 & 3.6 & 1.2 & 9.4 & 0.4 & 17.8 & 8.9 & 0.3 \\
T. durum var. falcatomelanopus & 8.3 & 10.3 & 10.6 & 0.7 & 4.5 & 2.4 & 0.1 \\
T. timopheevii & 4.8 & 2.8 & 6.0 & 1.1 & 0.8 & 2.8 & 0.5 \\
\hline
\end{tabular}


mer in our experiment and Polba 3 variety significantly $(\mathrm{p}<0.05)$ exceeded durum wheat variety Spadshchyna by the cooking coefficient. According to the scientific data, the cooking coefficient of groats from emmer lines varied from 2.53 to 3.19 (Malchikov PN, et al 2016), which is lower than for most our lines and varieties.

The duration of cooking groats depends on the size of its grains, thickness of cellular walls and time of starch gelatinization (Kumari M, 2019). Messia MC et al (2012) reported that the duration of cooking emmer porridge was 18-21 min. In our studies, the cooking time of all lines and varieties of spring emmer, durum wheat variety and $T$. timopheevii did not differ. Polba 3 variety had the shortest (25 min) cooking time. The accession T. durum var. falcatomelanopus was characterized by the longest cooking time (75 min). As starch gelatinization is one of the main factors, affecting the cooking time, these differences may be conditioned by the specificities of the structure of starch granules of Polba 3 variety and T. durum var. falcatomelanopus. The size of caryopsis of T. durum var. falcatomelanopus may reach up to 10 $\mathrm{mm}$, which may also explain the long cooking time of this accession, as the surface/volume ratio in this case means slower soaking, heating and, hence, cooking, of T. durum var. falcatomelanopus grain.

\section{CONCLUSIONS}

It was found that by the set of groats properties (groats output and cooking coefficient in combination with good palatability, aroma, consistency, and also easy threshing), breeding lines 10-79 and 10-139, which are recommended to submit to trials as sources of groats qualities, could be distinguished indeed as potential candidates. It would be reasonable to use T. timopheevii and T. durum var. falcatomelanopus accessions independently and not yet in crossings as donors, as they require improvement via breeding in terms of agronomic characteristics.

\section{ACKNOWLEDGEMENTS}

The authors of the article express their sincere gratitude to Viacheslav Stepanovych Liutenko, the specialist of the Laboratory of Genetics, Biotechnology, and Quality of the Plant Production Institute named after V.Ya. Yuriev, NAAS, for his assistance with statistical processing of data.

Adherence to ethical principles. This article does not relate to any studies using humans and animals as investigation subjects.

Conflict of interests. The authors deny any conflict of interests.
Financing. This study did not receive any specific grant from the financing institutions in state, commercial or non-commercial sectors.

\section{Вихідний матеріал для селекції пшениці полби звичайної ярої (Triticum dicoccum Shrank.) круп'яного напряму використання}

\author{
Л. А. Вечерська ${ }^{1 *}$, В. В. Любич ${ }^{2}$, Л. І. Реліна ${ }^{1}$,
}

О. В. Голік ${ }^{1}$, В. М. Сучкова ${ }^{3}$, Р. Л. Богуславський ${ }^{1}$

${ }^{1}$ Інститут рослинництва ім. В. Я. Юр'єва НААН, Харків Московський проспект, 142, Харків, 61000

${ }^{2}$ Уманський національний університет садівництва, Умань

Вул. Інститутська, 1, Умань, Черкаська область, 20305

${ }^{3}$ Національна академія аграрних наук України, Київ, Вул. Михайла Омеляновича-Павленка, 9, 01010

e-mail: lyudmila_vecherska@ukr.net*,lyubichv@gmail. com, lianaisaakovna@gmail.com,golik.oleg.vi@gmail. com,vsuchkova@ukr.net, boguslavr@meta.ua

Мета. Визначити зразки генофонду - джерела круп'яних властивостей у генетичному різноманітті полби звичайної ярої та споріднених видів пшениці. Методи. Біохімічні: вміст білка визначали за методом К'єльдаля; вміст крохмалю - методом інфрачервоної спектроскопії. Технологічні: склоподібність оцінювали шляхом розрізання 100 зерен і виражали у відсотках; плівчастість - відношенням кількості зерен, вкритих плівками, до загальної кількості зерен після обмолоту і виражали у відсотках; вміст та якість клейковини - шляхом відмивання ручним способом; твердозерність визначали на твердомірі YPD-300 (Ltpm China), за силою, необхідною для руйнування зернівки; крупу з полби отримували на лабораторному лущильнику УШЗ-1; визначення круп'яних властивостей проводили відповідно до методики, описаної в патенті на корисну модель № 129205. Статистичні: значущість відмінностей між зразками оцінювали за допомогою критерію Манна-Уітні для малих вибірок $з$ невідомим розподілом. При двофакторному дисперсійному аналізі розглядали 2 фактори - генотип та умови року. У кореляційному аналізі використовували критерій Пірсона. Варіабельність ознак оцінювали за коефіцієнтом варіації (КВ). Результати. Досліджено та проаналізовано рівень урожайності зразків сортів полби та пшениці твердої, а також ліній, одержаних з полб'яно-пшеничних гібридів упродовж 2016-2019 рр. Урожайність більшості зразків полби (крім Triticum timopheevii) була на рівні стандарту Голіковська (286 \pm $\left.\pm 15 \Gamma / \mathrm{M}^{2}\right)$. Найвищим вмістом білка та клейковини у зерні характеризувались $T$. timopheevii $(18,1 \pm 0,4 \%$ та 40,5 $\pm 1,8 \%$, відповідно), Triticum durum Desf. var. falcatomelanopus Jakubz. \& Filat. (17,5 $\pm 1,0 \%$ та $40,4 \pm 1,4 \%)$, автохтонний сорт Полба $3(16,8 \pm 0,1 \%$ 
та $36,9 \pm 1,1 \%)$, і лінія $10-139(14,8 \pm 0,8 \%$ та $29,0 \pm 2,4 \%$ ). У більшості ліній, отриманих у результаті схрещувань полби ярої з пшеницею твердою ярою, індекс деформації клейковини (ІДК) у межах 50-75 одиниць відповідає першій групі якості клейковини хороша. За рівнем склоподібності виділено T. timopheevii $(99 \pm 1 \%)$ та $T$. durum var. falcatomelanopus (75 $\pm 5 \%$ ). Рівень твердозерності досліджуваних зразків варіював від $151 \pm 15$ Н у сорту Романівська до $286 \pm 3 \mathrm{H}$ у T. timopheevii. Високим рівнем твердозерності характеризувались лінії 10-79 (255 \pm 6 Н), 10-65 (220 \pm 10 H) та T. durum var. falcatomelanopus $(268 \pm 6 \mathrm{H})$, які перевищували сорт пшениці твердої Спадщина $(152 \pm 13 \mathrm{H})$. Високим виходом крупи характеризувались лініі 10 $139(96,2 \pm 0,8 \%), 10-79(90,6 \pm 0,8 \%)$, T. timopheevii $(92,0 \pm 0,1 \%)$, пшениця тверда Спадщина $(91,4 \pm$ $\pm 0,5 \%$ ). Установлено низьку варіабельність (КВ < $10 \%$ ) показника твердозерності в усіх вивчених зразках. Висновки. Встановлено, що за комплексом круп'яних властивостей (вихід крупи та коефіцієнт разварюваності в поєднанні з хорошими смаком, ароматом, консистенцією, а також легким вимолотом) виділено селекційнілінії полби 10-79 та 10-139, які рекомендується випробувати як джерела круп'яних властивостей у селекції. Зразки T. timopheevii та T. durum var. falcatomelanopus доцільно використовувати як самостійні круп'яні культури, однак вони потребують селекційного покращення за агрономічними ознаками.

Ключові слова: Triticum dicoccum, T. timopheevii, T. durum, круп'яні властивості, плівчастість, білок, клейковина, твердозерність.

\section{REFERENCES}

Bobryk-Mamczarz A, Kiełtyka-Dadasiewicz A, Rachoń L. (2021). Usefulness of hulled wheats grown in polish environment for wholegrain pasta-making. Foods (Basel, Switzerland). 10(2):458. https://doi.org/10.3390/ foods 10020458.

Chaddock RE. (1925) Principles and Methods of Statistics. Houghton, Mifflin Company; 1st edition.

Chen Ye, Delaney L, Johnson S et al. (2017) Using near infrared spectroscopy to determine moisture and starch content of corn processing products. J. Near Infrared. Spectrosc. 25(5):348-359. https://doi.org/10.1177/09670 33517728146.

Čurná V, Lacko-Bartošová M. (2017) Chemical Composition and Nutritional Value of Emmer Wheat (Triticum dicoccon Schrank): a Review. J. Central Europ. Agric. 18(1):117-134. https://doi.org/10.5513/JCEA01/ 18.1.1871.

Dorofeev VF, Udachin RA, Semenova LV et al. (1987) Pshenitsy mira: vidovoy sostav, dostizheniya selektsii, sovremennye problemy i iskhodnyy material (Wheat of the world: species composition, breeding achievements, contemporary problems and the initial material.) 2nd edition. Agropromizdat. Leningrad. (in Rusian).

FAO and IUSS (2015) World Reference Base for Soil Resources 2014. International soil classification system for naming soils and creating legends for soil maps. World Soil Resources Reports № 106. FAO, Rome.

Geisslitz S, Longin CFH, Scherf KA, Koehler P. (2019) Comparative Study on Gluten Protein Composition of Ancient (Einkorn, Emmer and Spelt) and Modern Wheat Species (Durum and Common Wheat). Foods. 8(9):409. https://doi.org/10.3390/foods8090409.

Gorelick J, Yarmolinsky L, Budovsky A et al. (2017) The impact of diet wheat source on the onset of type 1 diabetes mellitus - lessons learned from the non-obese diabetic (NOD) Mouse Model. Nutrients. 9(5):482. https://doi. org/10.3390/nu9050482.

Hammami R, Sissons M. (2020) Durum wheat products, couscous. In: Igrejas G., Ikeda T., Guzmán C. (eds) Wheat Quality for Improving Processing and Human Health. Springer, Cham. https://doi.org/10.1007/978-3030-34163-3_15.

Haraszi R, Juhasz A, Sissons M, et al. (2013) Rheological hardness index for assessing hardness of hexaploids and durums. J. Cereal Chemistry. 90(5):430-438. https://doi. org/10.1094/CCHEM-10-12-0133-R.

Haraszi R, Sissons M, Juhasz A, et al. (2016) Using rheological phenotype phases to predict rheological features of wheat hardness and milling potential of durum wheat. Cereal Chem. 93(4):369-376. https://doi.org/10.1094/ CCHEM-12-15-0255-R.

Hütsch BW, Jahn D, Schubert S. (2018) Grain yield of wheat (Triticum aestivum L.) under long-term heat stress is sink-limited with stronger inhibition of kernel setting than grain filling. J. Agron. Crop Sci. 205(1):22-32. https://doi.org/10.1111/jac.12298.

Karagöz A. (2014) Wheat Landraces of Turkey. Emir. J. Food Agric. 26(2):149-156. doi:10.9755/ejfa.v26i2.16397.

Kohl S, Hollmann J, Erban A et al. (2015) Metabolic and transcriptional transitions in barley glumes reveal a role as transitory resource buffers during endosperm filling. J. Exp. Bot. 66(5):1397-1411. https://doi.org/10.1093/jxb/ eru492.

Kulathunga J, Reuhs BL, Zwinger S, Simsek S. (2021) Comparative study on kernel quality and chemical composition of ancient and modern wheat species: einkorn, emmer, spelt and hard red spring wheat. Foods. 10(761). https:// doi.org/10.3390/foods10040761.

Kumari M. 2019. Cereals. Walnut Publication.

Lachman J, Orsak M, Pivec V, Jiru K. (2012) Antioxidant activity of grain of einkorn (Triticum monococcum L.), emmer (Triticum dicoccum Schuebl [Schrank]) and spring wheat (Triticum aestivum L.) varieties. Plant Soil Environ. 58:15-21. https://doi.org/10.17221/300/2011-PSE.

Lakin GF. (1990) Biometriya (Statistical biology). Vysshaya Shkola. Moscow (in Russian). 
Lipinsky VM, Dyachuk VA, Babichenko VM. (2003) Climate of Ukraine. Kyiv. Raevsky Publishing House.

Liubych VV, Riabchun VK, Novikov VV et al. (2018) Sposib kulinarnoho otsiniuvannia krupianykh produktiv iz zerna pshenytsi, trytykale ta yachmeniu. Patent 129205 Ukraina, MPK A23L 35/00, A23L 7/00. No u 201804120; zaiavl.16.04.2018; opubl. 25.10.2018, Biul. № 20. (Method of culinary assessment of cereal products from grain wheats, triticale and barley grain. Patent of Ukraine for useful model 129205 IPC No U 201804120; declared 16.04.2018; published 25.10.2018, No 20. (in Ukrainian).

Longin CFH, Ziegler J, Schweiggert R et al. (2015) Comparative study of hulled (einkorn, emmer, and spelt) and naked wheats (durum and bread wheat): Agronomic performance and quality traits. Crop. Sci. 56:302-311. doi: 10.2135/cropsci2015.04.0242.

Ma X, Sajjad M, Wang J et al. (2017) Diversity, distribution of Puroindoline genes and their effect on kernel hardness in a diverse panel of Chinese wheat germplasm. BMC Plant Biol. 17(1):158. doi: 10.1186/ s12870-017-1101-8.

Malchikov PN, Zotikov VI, Sidorenko VS et al. (2016) Perspektivy uluchsheniya krupyanykh kachestv tverdoj psheniczy v protsesse selektsiy (Prospects for improving the quality of durum wheat groats in the selection process). Zernobobovyye i Krupyanyye Kultury 3(19): 101-108. 9 (in Russian).

Messia MC, Iafelice G, Marconi E. (2012) Effect of parboiling on physical and chemical characteristics and nonenzymatic browning of emmer (Triticum dicoccon Schrank). J. Cereal. Sci. 56:147-152. https://doi.org/10.1016/j.jcs. 2012.05.006.

Musienko MM, Gadzalo YaM, Kovalenko MS et al. (2019) Adaptation reactions of common wheat (Triticum aestivum L.) and emmer (T. dicoccum Schrank ex Schuebl.) seedlings under osmotic stress and treatment with metal nanoparticles. Agric. Sci. Pract. 6(3):3-13. doi: https:// doi.org/10.15407/agrisp6.03.003.

Nirmal RC, Furtado A, Wrigley C, Henry RJ. (2016) Influence of gene expression on hardness in wheat. PLoS ONE. 11(10):e0164746. https://doi.org/10.1371/journal. pone. 0164746 .

Okamoto Y, Takumi S. (2013) Pleiotropic effects of the elongated glume gene $\mathrm{P} 1$ on grain and spikelet shaperelated traits in tetraploid wheat. Euphytica. 194:207218. doi: 10.1007/s10681-013-0916-0.

Ozboy O, Koksel H. (2002) An application of linear regression technique for predicting bulgur yield and quality of wheats cultivars. Nahrung/Food. 46(1):21-24. https:// doi.org/10.1002/1521-3803(20020101)46:1<21::AIDFOOD21 $>3.0 . C O ; 2-F$.

Plant Production and Protection Division (2013) Genebank Standards for Plant Genetic Resources for Food and Agriculture. FAO. Rome, Italy
Righetti L, Rubert J, Galaverna G et al. (2016) Characterization and discrimination of ancient grains: a metabolomics approach. Int. J. Mol. Sci. 17(8):1217. doi: 10.3390/ijms 17081217.

S'aez-Plaza P, Michałowski T, Navas M et al. (2013a) An overview of the Kjeldahl method of nitrogen determination. Part I. Early history, chemistry of the procedure, and titrimetric finish. Critic. Rev. Analyt. Chem. 43(4):178-223. https:// doi:10.1080/10408347.2012.7 51786 .

S'aez-Plaza P, Navas MJ, Wybraniec S et al. (2013b) An overview of the Kjeldahl method of nitrogen determination. Part II. Sample preparation, working scale, instrumental finish, and quality control. Critic. Rev. Analyt. Chem. 43(4):224-272. https://doi.org/10.1 080/10408347.2012.751787.

Shewry PR, Hey SJ. (2015) The contribution of wheat to human diet and health. Food Energ. Secur. 4(3):178-202. https://doi.org/10.1002/fes3.64.

Smirnov O, Karpets L-A, Zinchenko A et al. (2020) Changes of morphofunctional traits of Triticum aestivum and Triticum dicoccum seedlings caused by polyethylene glycol-modeling drought. J. Centr. Europ. Agric. 21(2):268-274. doi: 10.5513/JCEA01/21.2.2341.

Sofi F, Whittaker A, Cesari F et al. (2013) Characterization of Khorasan wheat (Kamut) and impact of a replacement diet on cardiovascular risk factors: Cross-over dietary intervention study. Europ. J. Clin. Nutr. 67(2):1-6. doi: 10.1038/ejcn.2012.206.

Thorup AC, Gregersen S, Jeppesen PB. (2014) Ancient wheat diet delays diabetes development in a Type 2 Diabetes animal model. Rev. Diabet. Stud. Fall-Winter. 11(3-4):245-257. doi: 10.1900/RDS.2014.11.245.

Tkachyk SO, Kienko ZB, Prysyazhniuk LM et al. (2016) Metodyka provedennia kvalifikatsiinoi ekspertyzy sortiv roslyn na prydatnist do poshyrennia v Ukraini. Metody vyznachennia pokaznykiv yakosti produktsii roslynnytstva (Methods of qualification examination of plant varieties for suitability for dissemination in Ukraine. Methods for determining the quality of crop products). Ukrainian Institute of Plant Variety Examination. Vinnytsia. 159 p. ISBN 978-966-924-578-6. (in Ukrainian). Vasyliev SV. (2017) Kharakterystyka polby yak perspektyvnoi zernovoi kultury ta osnovni problemy yii pisliazbyralnoho obroblennia (Description of the spelt as a promising grain crop and main problems of its postharvest processing). Zernovi Produkty i Kombi-kormy. 17(1):1622. doi.org/10.15673/gpmf.v17i1.309.(in Ukrainian).

Vecherska LA, Relina LI, Bohuslavskyi RL, Golik OV. (2019) Morphogenesis in early generations of winter emmer / durum winter wheat hybrids. Genetičnì Resursi Roslin. 25:71-81. doi: 10.36814 \pm pgr.2019.25.05.

Veha A, Szabó PB, Gyimes E. (2011) Different method to determine the kernel hardness of Hungarian winter wheat varieties, 7 th International Conference Integrated 
VECHERSKA et al.

Systems for Agri-Food Production, Sipa. Nyíregyháza, Hungary: 10-12.

Yarosh AV, Ryabchun VK, Leonov OYu et al. (2014) Metodolohiia otsinky tverdosti zerna u pshenytsi miakoi ozymoi (The methodology of assessing grain hardness of winter bread wheats). Genetičnì Resursi Roslin. 15:120131. (in Ukrainian).

Yilmaz VA. (2020) Effects of several production methods on technological, textural, and sensorial properties of emmer (Triticum turgidum ssp. dicoccum) bulgur. J. Food Sci. Technol. 57:3874-3883. https://doi.org/10.1007/s13197020-04419-0.
Zaharieva M, Ayana NG, Hakimi AA et al. (2010) Cultivated emmer wheat (Triticum dicoccon Schrank), an old crop with promising future: a review. Genet. Resour. Crop Evol. 57:937-962. doi: 10.1007/s10722010-9572-6.

Zhygunov D, Kovalov M, Kovalova V. (2017) Doslidzhennia perevah i nedolikiv pry vyznachenni kleikovyny avtomatyzovanym i ruchnym sposobom (Study of advantages and sleeves in determining gluten by automated and manual mode). Zernovi Produkty i Kombikormy, 17(3): 21-26. https://doi.org/10.15673/gpmf.v17i3.657 (in Ukrainian). 